\title{
Partisipasi Masyarakat dalam Menciptakan Keamanan dan Ketertiban Masyarakat
}

\author{
Thelma Wawointana \\ UNIMA \\ Tondano, Indonesia \\ thelmawawointana@unima.ac.id
}

Abstrak- Penelitian ini bertujuan untuk menganalisis dan menjelaskan bentuk partisipasi masyarakat dalam menciptakan keamanan dan ketertiban masyarakat. Jenis penelitian ialah kualitatif, dengan pendekatan studi kasus. Hasil penelitian menemukan bahwa bentuk partisipasi masyarakat dalam menciptakan keamanan dan ketertiban hanya sebagian masyarakat saja yang secara sadar berpartisipasi dalam menjaga keamanan dan ketertiban di dalam masyarakat. Peran elit lokal masih kurang dalam berpartisipasi, yang terjadi hanya karena ada muatan kepentingan. Para tokoh masyarakat dan tokoh agama yang ada dalam struktur forum Mapalus Kamtibmas secara formal dimasukkan dalam forum tapi kenyataannya mereka tidak berfungsi. Dukungan Politik Anggota DPRD hampir tidak pernah terlihat kecuali pada saat-saat kampanye. Mereka muncul hanya pada saat kampanye untuk merebut suara masyarakat tapi setelah itu hampir tidak pernah terlihat lagi. Lembaga legislatif itu pula tidak pernah terlibat langsung dalam kegiatan mapalus kamtibmas. Peran lembaga legislatif sebagai bagian dari representatif masyarakat belum menjalankan tugas politiknya dalam fungsi budgeting (penganggaran) sehingga dukungan anggaran di tingkat kabupaten sama sekali tidak ada dan kurang mendukung. Hambatan partisipasi dapat disimpulkan bahwa hambatan yang utama partisipasi masyarakat ialah lemahnya sosialisasi dan koordinasi dari pembuat kebijakan. Selanjutnya lemahnya koordinasi antara pemerintah Provinsi dengan Pemerintah Kabupaten secara vertikal. Selanjutnya pelibatan masyarakat hanya pada hal-hal yang sifatnya temporer atau sementara, dalam hal ini peran pemerintah sebagai pembuat kebijakan sangat lemah dan tidak optimal.

KATA KUNCI: Partisipasi Masyarakat, keamanan, ketertiban masyarakat.

\section{PENDAHULUAN}

Penciptaan keamanan dan ketertiban masyarakat di daerah dari berbagai ancaman dan gangguan, seperti tindakan kriminalitas dan konflik sosial merupakan tanggung jawab bersama. Perhatian pada sektor pertahanan dan keamanan sangat penting karena berkaitan dengan tuntutan masyarakat akan jaminan keamanan dan ketertiban serta sebagai wujud pertanggungjawaban institusi negara. Oleh karena itu, pemerintah/negara harus mampu memberi rasa aman, kepastian, dan jaminan dalam pelayanan masyarakat. Pemerintah juga harus mensosialisasikan program pemberdayaan masyarakat, sehingga masyarakat dapat terhindar dari ancaman dan gangguan yang bersifat internal, baik berupa konflik antar-kampung, konflik antarsuku, agama, maupun ancaman external seperti kejahatan, teror serta bentuk kekerasan lainnya. Dengan kata lain, masyarakat membutuhkan sebuah kondisi keamanan dan ketertiban yang kondusif, serta penanganan kriminalitas secara baik. Untuk itu diperlukan partisipasi masyarakat dalam menciptakan keamanan dan ketertiban masyarakat.

Partisipasi masyarakat dalam upaya menciptakan keamanan dan ketertiban merupakan sebuah tuntutan yang harus diwujudkan dalam era otonomi sekarang ini. Otonomi daerah akan menciptakan kemandirian daerah termasuk menjaga keamanan dan ketertiban bersama. Tentu 
saja keamanan dan ketertiban tersebut tidak akan terwujud, tanpa peran serta atau partisipasi masyarakat. Oleh karena itu partisipasi masyarkat merupakan salah satu faktor yang menentukan berjalannya suatu kebijakan pemerintah.

Munculnya beragam masalah sosial seperti tindakan-tindakan kriminal yang melanda di Kabupaten Minahasa membuktikan tingkat kejahatan mengalami peningkatan. Hal itu seperti di ungkapkan oleh Henny Posumah mantan Kapolres Minahasa bahwa angka tindakan kejahatan semakin meningkat bahkan dilihat dari kualitas kejahatan pun terus meningkat. Jenis kejahatan yang mengalami peningkatan yaitu: pencurian dengan kekerasan, penganiayaan, kejahatan jalanan, pencurian kendaraan bermotor, pembunuhan, premanisme dan kejahatan narkoba. Hal ini sering terjadi dan mewarnai disetiap berita di daerah Kabupaten Minahasa.

Perilaku-perilaku menyimpang yang dilakukan oleh anggota masyarakat perlu mendapat perhatian karena hal itu dapat menimbulkan ketidakamanan, tidak memiliki rasa kekeluargaan, kebersamaan, gotong royong, tolong menolong bahkan tidak peduli dengan kehidupan di sekelilingnya. Tidak mengherankan lagi kemudian menimbulkan masalah-masalah sosial yang meresahkan kehidupan dalam kemasyarakatan dan mendorong terjadinya konflik sosial. Perilaku manusia yang cenderung cepat marah dan suka merusak dan mengakibatkan bencana sosial, tawuran, koflik horisontal, dipandang sebagai akibat melemahnya bahkan punahnya nilai-nilai kearifan lokal dan norma-norma kelembagaan sosial yang semula dimiliki oleh kelompokkelompok masyarakat tradisional (Manado Post, 30 Maret 2014).

Menurut Edward III agar implementasi kebijakan berjalan efektif tersebut yakni memperhatikan faktor-faktor seperti: a) komunikasi, kebijakan harus dikomunikasikan pada pihak tekait kebijakan dan masyarakat baik yang menjadi sasaran maupun yang tidak menjadi sasaran kebijakan; b) ketersediaan sumberdaya, implementasi kebijakan membutuhkan tersedianya sumberdaya yang berkualitas atau kompeten sesuai tujuan kebijakan; c) Sikap, implementasi kebijakan akan berhasil apabila pihak terkait memiliki sikap dan komitmen yang kuat untuk mencapai keberhasilan kebijakan; dan d) Struktur organisasi, implementasi kebijakan akan mudah diimplementasikan apabila sebelum dan sementara implementasi ditunjang dengan struktur birokrasi yang menunjang implemenasi.

Untuk menilai apakah kebijakan publik tersebut berdampak bagi publik, maka Dunn (2013:610), mengemukakan beberapa kriteria diantaranya: a) menilai apakah hasil yang diinginkan telah tercapai, b) menilai seberapa banyak usaha diperlukan untuk mencapai keberhasilan yang diinginkan, c) menilai seberapa jauh pencapaian hasil yang diinginkan dalam memecahkan masalah, d) menilai apakah biaya dan manfaat didistribusikan dengan merata kepada sasaran, e) menilai apakah hasil kebijakan memuaskan dan f) menilai manfaat pada masyarakat di luar sasaran dang) menilai apakah hasil kebijakan berguna atau bernilai bagi masyarakat.

\section{A. Partisipasi Msyarakat}

Kata "partisipasi masyarakat" dalam pembangunan menunjukkan pengertian pada keikutsertaan masyarakat dalam perencanaan, pelaksanaan, pemanfaatan hasil dan evaluasi program pembangunan. Kebijakan nasional dewasa ini, selalu melibatkan masyarakat dalam berbagai kegiatan pembangunan. Partisipasi masyarakat dalam kegiatan pembangunan ialah merupakan suatu konsekuensi logis dari implementasi Undang-Undang Nomor 22 Tahun 1999 tentang Pemerintahan Daerah.

Menurut Wasistiono (2002: 32), Ciri-ciri tata pemerintahan yang baik adalah: 1). mengikutsertakan semua masyarakat; 2) transparan dan bertanggung jawab; 3) efektif dan adil; dan 4) menjamin adanya supremasi hukum. Selanjutnya menurut Wasistiono (2002: 33) syarat utama warga negara disebut berpartisipasi dalam kegiatan berbangsa, bernegara dan 
berpemerintahan, yaitu 1) ada rasa kesukarelaan (tanpa paksaan); 2) ada keterlibatan emosional; dan 3) memperoleh manfaat secara langsung maupun tidak langsung dari keterlibatannya.

Partisipasi masyarakat merupakan suatu proses teknis untuk memberikan kesempatan dan wewenang yang lebih luas kepada masyarakat untuk secara bersama-sama memecahkan berbagai persoalan pembangunan. Partisipasi masyarakat ini dilakukan berdasarkan tingkat keikutsertaan (level of involvement) masyarakat dalam kegiatan pembangunan tersebut. Partisipasi masyarakat bertujuan untuk mencari solusi dari permasalahan yang dihadapi agar dapat terpecahkan. Dengan membuka lebih banyak kesempatan bagi masyarakat untuk ikut memberikan kontribusi sehingga implementasi kegiatan pembangunan berjalan lebih efektif, efesien, dan berkelanjutan.

Partisipasi sering digunakan di dalam kajian tentang peranan anggota masyarakat baik formal maupun non formal. Partisipasi masyarakat dalam pelaksanaan pembangunan sangat diperlukan untuk keberhasilan program yang diinginkan. Suatu program yang menyangkut aspek ekonomi, ssosial dan budaya keamanan dan ketertiban masyarakat tidak akan berhasil tanpa peran aktif masyarakat, baik kedudukannya sebagai obyek maupun subyek dalam pengembangan pembangunan yang ada di daerah.

Menurut Davis and Newstrom partisipasi adalah keterlibatan mental/pikiran dan emosi/perasaan seseorang di dalam situasi kelompok yang mendorong untuk memberikan sumbangan kepada kelompok dalam usaha mencapai tujuan serta turut bertanggung jawab terhadap usaha yang bersangkutan. Ada tiga gagasan penting dalam definisi ini yaitu: keterlibatan, kontribusi dan tanggung jawab. Sejalan dengan itu Makmur (2009: 130) menyatakan partisipasi mempunyai tiga unsur yaitu: 1) keikutsertaan secara mental yang tergambarkan dalam perasaan; 2) akal yang dinampakkan terhadap pola pikir; 3) tanggung jawab yang digambarkan dalam perbuatan.
Partisipasi masyarakat menurut Isbandi (2007:27) adalah keikutsertaan masyarakat dalam proses pengidentifikasian masalah dan potensi yang ada di masyarakat, pemilihan dan pengambilan keputusan tentang alternatif solusi untuk menangani masalah, pelaksanaan upaya mengatasi masalah, dan keterlibatan masyarakat dalam proses mengevaluasi perubahan yang terjadi. Menurut Muluk (2010: 8-10) Partisipasi masyarakat terdiri atas sub-sub sistem yaitu, 1) aktivitas partisipasi masyarakat, 2) pendidikan politik masyarakat, 3) kesadaran berpartisipasi masyarakat, 4) organisasi lokal, 5) elit lokal, 6) dukungan pemerintah daerah, 7) dukungan DPRD, dan 8) dukungan pemerintah pusat.

Desentralisasi di bidang pemerintahan atau otonomi adalah menyerahkan kewenangan untuk mengatur dan menyelenggarakan pemerintah kepada daerah. Penyerahan ini berarti memberikan kesempatan kepada aparat daerah, termasuk wakil-wakil rakyatnya untuk berpartisipasi di dalam merencanakan dan melaksanakan berbagai kebijaksanaan pembangunan tanpa harus mendapat arahan dan atau diarahkan oleh pusat (top-down atau bottom up). Dengan demikian pembangunan di daerah akan lebih berorientasi pada kebutuhan setempat (bottom up oriented) sesuai dengan perencanaan dan kemampuan serta kebutuhan di daerah dan bukan didasarkan kepada kemauan yang dari pusat saja.

\section{B. Jenis Partisipasi Masyarakat}

Partisipasi dalam pelaksanaan pembangunan suatu daerah sangat penting dimasyarakatkan kepada semua pelaku yang terlibat. Partisipasi tidak berarti hanya berasal dari rakyat dan masyarakat, atau hanya dari pemerintah saja, tetapi partisipasi harus datang dari semua pihak baik rakyat atau masyarakat maupun pemerintah, pihak swasta, dan lain-lain. Jadi jelas bahwa yang dimaksud dengan partisipasi ialah kemampuan sistem pengelolaan sumber daya yang ada dalam pelaksanaan pembangunan untuk membuka kesempatan seluas-luasnya kepada semua pihak 
yang terlibat dalam pelaksanaan untuk mengambil bagian secara aktif, mulai dari kegiatan identifikasi masalah, perencanaan, pelaksanaan, pengawasan, pemantauan, dan evaluasi.

Partisipasi masyarakat menurut Isbandi (2007) adalah keikutsertaan masyarakat dalam proses pengidentifikasian masalah dan potensi yang ada di masyarakat, pemilihan dan pengambilan keputusan tentang alternatif solusi untuk menangani masalah, pelaksanaan upaya mengatasi masalah, dan keterlibatan masyarakat dalam proses mengevaluasi perubahan yang terjadi. Mikkelsen (2001) membagi partisipasi menjadi 6 (enam) pengertian, yaitu:

1. Partisipasi adalah kontribusi sukarela dari masyarakat kepada proyek tanpa ikut serta dalam pengambilan keputusan;

2. Partisipasi adalah "pemekaan" (membuat peka) pihak masyarakat untuk meningkatkan kemauan menerima dan kemampuan untuk menanggapi proyekproyek pembangunan;

3. Partisipasi adalah keterlibatan sukarela oleh masyarakat dalam perubahan yang ditentukannya sendiri;

4. Partisipasi adalah suatu proses yang aktif, yang mengandung arti bahwa orang atau kelompok yang terkait, mengambil inisiatif dan menggunakan kebebasannya untuk melakukan hal itu;

5. Partisipasi adalah pemantapan dialog antara masyarakat setempat dengan para staf yang melakukan persiapan, pelaksanaan, monitoring proyek, agar supaya memperoleh informasi mengenai konteks lokal, dan dampak-dampak sosial;

6. Partisipasi adalah keterlibatan masyarakat dalam pembangunan diri, kehidupan, dan lingkungan mereka.

Partisipasi masyarakat dalam pelaksanaan pembangunan lebih menekankan kepada kemauan sendiri secara sadar untuk melaksanakan aktivitasativitas pembangunan, disini semua potensi manusia (tenaga kasar dan terampil serta dana) diarahkan bagi pelaksanaan pembangunan baik melalui swadaya gotong royong maupun sumbangan sukarela (Koentjaraningrat, 1985).

Menurut Conyers (1994:154) menyatakan bahwa masyarakat akan lebih mempercayai proyek atau program pembangunan jika merasa dilibatkan dalam proses dan perencanaannya karena mereka akan lebih mengetahui seluk beluk proyek tersebut dan akan mempunyai rasa memiliki. Sedangkan menurut Slamet (1992) Partisipasi adalah proses aktif dan inisiatif yang muncul dari masyarakat serta akan terwujud sebagai suatu kegiatan nyata apabila terpenuhi oleh tiga faktor pendukungnya yaitu: (1) adanya kemauan, (2) adanya kemampuan, dan (3) adanya kesempatan untuk berpartisipasi.

Selanjutnya menurut Cohen and Uphoff (1980) Ada empat jenis partisipasi antara lain meliputi: 1) partisipasi dalam pengambilan keputusan; 2) partisipasi dalam implementasi; 3) partisipasi dalam pemanfaatan; dan 4) partisipasi dalam evaluasi. Sedangkan menurut Muluk (2007: 178) bahwa partisipasi masyarakat terdiri atas sub-sub sistem yaitu: 1) aktivitas partisipasi masyarakat, 2) pendidikan politik masyarakat, 3) kesadaran berpartisipasi masyarakat, 4) organisasi lokal, 5) elit lokal, 6) dukungan pemerintah daerah, 7) dukungan DPRD, 8) dukungan pemerintah pusat.

\section{Pelaksanaan Partisipasi}

Menurut Iswantoro, mengingat keragaman masyarakat tersebut, siapa yang berpartisipasi dapat dibagi menjadi empat kategori, yaitu: 1) Masyarakat lokal (umur, jenis kelamin, pekerjaan, pendapatan, dan tempat tinggal); 2) Tokoh masyarakat (pemimpin lokal/informal); 3) Personil pemerintah; 4) Personil asing (dari luar). Ciri-ciri tersebut mungkin tidak semuanya cocok untuk semua kegiatan atau program, namun demikian beberapa kombinasi dari ciri-ciri tersebut akan berguna untuk menentukan "siapa" yang berpartisipasi dalam berbagai tahap kegiatan pembangunan. Jadi semua stakeholder (masyarakat, pemerintah, lembaga non pemerintah/LSM dan lembaga lainnya) harus berperan aktif untuk dapat menjalankan suatu 
kegiatan atau suatu program pelaksanaan pembangunan di daerahnya.

Bertolak dari pandangan tersebut di atas, dalam upaya memotivasi masyarakat untuk berpartisipasi melalui kegiatan mapalus, diperlukan pula pemimpin yang dapat dijadikan panutan. Pemuka masyarakat desa dapat merupakan motivator utama kegiatan mapalus sehingga pastisipasinya sangat diperlukan. Selama ini pemimpinpemimpin di desa memiliki pengaruh apabila mereka memperoleh legitimasi secara formal ataupun informal.

Menurut Tjokrowinoto (1977: 26) yang diperlukan adalah pandangan masyarakat tentang tingkat legitimasi pemuka masyarakat desa. Dikatakannya bahwa makin tinggi legitimasi institusi di dalam pandangan masyarakat, makin besar pula kesediaan masyarakat untuk menyesuaikan pandangan dan pola tingkah laku masyarakat kepada kehendak institusi tersebut. Maka dari itu, makin tinggi tingkat loyalitas dan komitmen masyarakat, makin tinggi pula partisipasi masyarakat terhadap kegiatan-kegiatan yang didorong oleh institusi tersebut.

Pendapat Tjokrowinoto ini, secara analog dapat dikatakan bahwa semakin tinggi legitimasi masyarakat terhadap keberadaan tokoh masyarakat desa, semakin tinggi pula perannya dalam memotivasi pelestarian budaya mapalus di desa. Namun, bagaimana tokoh-tokoh masyarakat desa ini dapat memotivasi masyarakat desa dalam kegiatan-kegiatan mapalus atau kegiatan-kegiatan pembangunan, hal ini dapat diwujudkan melalui keikutsertaan mereka secara langsung dalam kegiatan mapalus keamanan dan ketertiban di desa

Kemauan dan kemampuan berpartisipasi berasal dari yang bersangkutan (warga atau kelompok masyarakat), sedangkan kesempatan berpartisipasi datang dari pihak luar yang memberi kesempatan. Apabila ada kemauan tapi tidak ada kemampuan dari warga atau kelompok dalam suatu masyarakat, sungguhpun telah diberi kesempatan oleh negara atau penyelenggara pemerintahan, maka partisipasi tidak akan terjadi. Demikian juga, jika ada kemauan dan kemampuan tetapi tidak ada ruang atau kesempatan yang diberikan oleh negara atau penyelenggara pemerintahan untuk warga atau kelompok dari suatu masyarakat, maka tidak mungkin juga partisipasi masyarakat itu terjadi.

Partisipasi masyarakat adalah peran serta secara sukarela baik secara mental, spiritual, pikir dan emosi atau perasaan seseorang di dalam suatu kelompok masyarakat yang mendorong untuk memberikan sumbangan kepada masyarakat dalam usaha mencapai tujuan serta turut bertanggung jawab terhadap usaha yang bersangkutan. Ada empat unsur penting dalam definisi ini yaitu: peran serta, sumbangan, masyarakat dan tanggung jawab.

Selama ini, penyelenggaraan partisipasi masyarakat di Indonesia dalam kenyataannya masih terbatas pada keikutsertaan anggota masyarakat dalam implementasi atau penerapan program-program pembangunan saja. Kegiatan partisipasi masyarakat masih lebih dipahami sebagai upaya mobilisasi untuk kepentingan pemerintah atau negara. Partisipasi tersebut idealnya berarti masyarakat ikut menentukan kebijakan pemerintah yaitu sebagai bagian dari kontrol masyarakat terhadap kebijakan-kebijakan pemerintah.

Implementasi partisipasi masyarakat, seharusnya anggota masyarakat merasa bahwa tidak hanya menjadi objek dari kebijakan pemerintah, tetapi harus dapat mewakili masyarakat itu sendiri sesuai dengan kepentingan mereka. Perwujudan partisipasi masyarakat dapat dilakukan, baik secara individu atau kelompok, bersifat spontan atau terorganisasi, secara berkelanjutan atau sesaat, serta dengan cara-cara tertentu yang dapat dilakukan.

Partisipasi masyarakat dalam bidang kamtibmas perlu ditumbuh-kembangkan agar adanya kemauan dan kemampuan warga atau kelompok masyarakat untuk berpartisipasi dalam memelihara keamanan dan ketertiban dalam masyarakat melalui berbagai bentuk kegiatan seperti memberikan sumbangan berupa pemikiran, 
tenaga, waktu, keahlian, dana atau materi serta dapat menikmati hasil-hasilnya.

Institusi lokal dengan demikian merupakan faktor dominan dalam menggerakkan partisipasi. Partisipasi masyarakat itu dapat didorong atau dirangsang oleh pemerintah atau tokoh masyarakat yang ada di daerah. Karena partisipasi mereka cenderung tidak efektif jika berada diluar konteks organisasi. Karena di daerah pedesaan organisasi lokal merupakan faktor yang sangat penting dalam usaha pembangunan desa (Uphoff dan Esman, 1999).

\section{Konsep Keamanan dalam Negeri}

Pembukaan UUD 1945 mengamanatkan bahwa tujuan nasional, yaitu melindungi segenap bangsa Indonesia dan seluruh tumpah darah Indonesia, memajukan kesejahteraan umum, mencerdaskan kehidupan bangsa dan ikut melaksanakan ketertiban dunia yang berdasarkan kemerdekaan, perdamaian abadi dan keadilan sosial. Untuk mencapai tujuan nasional tersebut memerlukan upaya bersama segenap bangsa Indonesia.

Pertahanan dan ketahanan Indonesia adalah suatu upaya seluruh rakyat Indonesia dalam mempertahankan dan mengamankan negara demi kelangsungan hidup bangsa dan Negara Kesatuan Republik Indonesia. Dalam UUD 1945 pasal 30 ayat (1) berbunyi Tiap-tiap warga negara berhak dan wajib ikut serta dalam usaha pertahanan dan keamanan negara. Usaha pertahanan dan keamanan negara dilaksanakan melalui sistem pertahanan dan keamanan rakyat semesta oleh TNI dan Kepolisian Negara Republik Indonesia, sebagai kekuatan utama dan rakyat sebagai kekuatan pendukung (pasal 30 ayat (2) UUD 1945).

Konsepsi keamanan nasional Indonesia, paling tidak dapat dilakukan dengan mengetahui doktrin dan perundang-undangan yang menjadi landasan. Undang-Undang No. 34 tahun 2004 tentang Tentara Nasional Indonesia (TNI), Pasal 1 ayat (5) "Pertahanan negara adalah segala usaha untuk menegakkan kedaulatan negara, mempertahankan keutuhan wilayah NKRI dan melindungi keselamatan segenap bangsa dari ancaman dan gangguan terhadap keutuhan bangsa dan negara disusun dengan mempertahankan kondisi geografis Indonesia sebagai negara kepulauan”.

Menurut Undang-Undang TNI, tugas pokok TNI adalah menegakkan kedaulatan negara, mempertahankan keutuhan wilayah Negara Kesatuan Republik Indonesia yang berdasarkan Pancasila dan Undang-Undang Dasar Negara Republik Indonesia Tahun 1945, serta melindungi segenap bangsa dan seluruh tumpah darah Indonesia dari ancaman dan gangguan terhadap keutuhan bangsa dan negara.

Selanjutnya dilihat dari Undang-Undang No. 2 Tahun 2002 tentang Kepolisian Negara RI, Pasal 1 ayat (1) "Keamanan dalam negeri adalah suatu keadaan yang ditandai dengan terjaminnya kamtibmas, tegaknya hukum, serta terselenggaranya perlindungan, pengayoman, dan pelayanan kepada masyarakat".

Menurut Undang-Undang Kepolisian Negara, keamanan dan ketertiban masyarakat adalah suatu kondisi dinamis masyarakat sebagai salah satu prasyarat terselenggaranya proses pembangunan nasional dalam rangka tercapainya tujuan nasional yang ditandai oleh terjaminnya keamanan, ketertiban, dan tegaknya hukum, serta terbinanya ketenteraman, yang mengandung kemampuan membina serta mengembangkan potensi dan kekuatan masyarakat dalam menangkal, mencegah, dan menanggulangi segala bentuk pelanggaran hukum dan bentuk-bentuk gangguan lainnya yang dapat meresahkan masyarakat.

Undang-Undang No. 3 tahun 2002 tentang Pertahanan Negara, Pasal 1 ayat (1) "Pertahanan negara adalah segala usaha untuk mempertahankan kedaulatan negara, keutuhan wilayah NKRI dan keselamatan segenap bangsa dari ancaman dan gangguan terhadap keutuhan bangsa dan negara. Menurut Undang-Undang Pertahanan Negara ini, sistem pertahanan negara adalah sistem pertahanan yang bersifat semesta yang melibatkan seluruh warga negara, wilayah, dan sumber daya nasional lainnya, serta dipersiapkan secara dini oleh pemerintah dan 
diselenggarakan secara total, terpadu, terarah, dan berlanjut untuk menegakkan kedaulatan negara, keutuhan wilayah, dan keselamatan segenap bangsa dari segala ancaman".

Menurut Undang-Undang No. 3 Tahun 2002 tentang Pertahanan Negara mengidentifikasi bahwa sumber ancaman terhadap Indonesia dengan posisi geografis yang terbuka bersifat kompleks, tidak hanya dalam bidang militer, melainkan juga dalam bidang non militer, baik dari dalam maupun dari luar. Paling signifikan ialah bahwa batas antara sumber ancaman yang berasal dari dalam dan dari luar menjadi semakin kabur karena keterkaitan internasional, penyebaran nilai-nilai demokrasi, kemajuan dan penyebaran teknologi informasi dan sebagainya. Masalah ekonomi, lingkungan hidup, konflik sosial dan budaya, kejahatan internasional (transnational crimes) dan terorisme internasional tidak dapat dibendung semata-mata dengan menggunakan kekuatan militer. Karena itu kebijakan pertahanan negara harus bersifat komprehensif.

Keamanan dan Ketertiban Masyarakat, merupakan kebutuhan primer setiap makhluk hidup. Kehidupan yang damai dan dicita-citakan banyak orang yaitu kehidupan tentram, damai dalam keluarga, lingkungan maupun masyarakat. Untuk memperoleh kehidupan yang dimaksud dibutuhkan kehidupan yang tertib baik dalam rumah tangga, lingkungan maupun masyarakat. Oleh karena itu keamanan dan ketertiban masyarakat merupakan dambaan bersama, dan perlu diupayakan, direncanakan, dipelihara serta dipatuhi. Keamanan membutuhkan upaya, perencanaan, dan partisipasi dalam memeliharanya, sedangkan ketertiban masyarakat perlu pula diatur, dipelihara dan dipatuhi. Kedua hal ini merupakan satu mata uang yang saling melengkapi satu dengan yang lain untuk menciptakan kehidupan yang aman, nyaman dan tenteram penuh kedamaian.

Persoalan mendasar yang dihadapi kepolisian yaitu belum adanya kemampuan aparat kepolisian mewujudkan rasa aman di dalam masyarakat serta belum mampu memberi pelayanan yang optimal pada masyarakat. Seperti dikatakan Jusuf yang ditegaskan kembali oleh Rianto \& Lestari (2012: 7) bahwa tugas menyelesaikan perkara itu terkesan lebih heroik dan mendatangkan keuntungan baik berupa materi maupun karier daripada Polisi yang suka menolong dan bersamasama menjaga keamanan dan ketertiban di masyarakat.

\section{E. Mapalus Keamanan dan Ketertiban Masyarakat (Kamtibmas)}

Diberlakukannya UU Nomor 32 Tahun 2004 merupakan perwujudan demokrasi melalui desentralisasi, dengan demikian konsekuensinya ialah otonomi daerah. Dengan otonomi daerah, pemerintah daerah dan DPRD diharapkan dalam membuat kebijakan-kebijakan peraturan daerah harus berorientasi partisipatif-populis. Kebijakankebijakan partisipatif-populis yang tertuang dalam bentuk peraturan daerah seyogyanya dapat menjamin keadilan dalam masyarakat (Sarundajang, 2005: 320). Kebijakan itu seyogyanya kebutuhan masyarakat dilayani oleh pemerintah, begitu juga sebaliknya kebijakan pemerintah benar-benar didukung oleh masyarakat dengan demikian terciptalah pola pikir top-down dan bottom-up yang saling berinteraksi dalam hal kebutuhan akan adanya kebijakan pelayanan pemerintah terhadap masyarakat.

Adapun maksud dan tujuan pemberian otonomi daerah ialah 1) peningkatan pelayanan dan kesejahteraan masyarakat yang semakin baik; 2) pengembangan kehidupan demokrasi; 3) distribusi pelayanan yang semakin baik; 4) penghormatan terhadap budaya lokal; 5) perhatian atas potensi dan keanekaragaman daerah. Untuk penghormatan terhadap budaya lokal maka pemerintah daerah provinsi Sulawesi Utara mengangkat mapalus sebagai budaya lokal menjadi suatu kebijakan dengan di keluarkan Pergub. Sulawesi Utara No. 8 Tahun 2012 tentang Pembentukan Forum Mapalus Kamtibmas.

Menurut Pergub No. 8 tahun 2012 (pasal 1 ayat 1) di jelaskan bahwa, Mapalus Kamtibmas 
adalah Semangat Gotong Royong, menghimpun dan melibatkan aparat keamanan Pemerintah Desa/Kelurahan dengan masyarakat untuk saling menolong dan bekerjasama secara aktif dalam mencari akar permasalahan, memecahkan masalah Sosial serta mencari solusi dalam rangka mewujudkan kenyamanan, keamanan dan ketertiban masyarakat untuk terlaksananya program pembangunan, pemerintahan dan kemasyarakatan yang ada di Desa/Kelurahan.

Tujuan pembentukan forum ini adalah untuk memberikan pembinaan dan meningkatkan kesadaran masyarakat agar mampu dan dapat memelihara ketertiban, keamanan dan menanggulangi bencana alam serta menjaga/melindungi keselamatan jiwa, harta benda dari berbagai ancaman baik dalam maupun dari luar (pasal 2). Forum mapalus kamtibmas ini adalah wadah bersama yang menghimpun dan melibatkan aparat keamanan desa/kelurahan dengan masyarakat dalam rangka mewujudkan kenyamanan, keamanan dan ketertiban masyarakat yang ada di desa/kelurahan (pasal 4).

Adapun yang menjadi tugas pokok forum mapalus kamtibmas adalah: 1) melaksanakan tugas pokok, fungsi dan peranan masing-masing sesuai dengan peraturan perundang-undangan; 2) dalam pelaksanaan Mapalus Kamtibmas unsur pelaksana melaksanakan tugas secara bersamasama melakukan pembinaan dan pemberdayaan masyarakat desa, mencari dan mengumpulkan data/informasi tentang potensi bencana alam, non alam dan bencana sosial serta permasalahan di bidang ideologi, politik, ekonomi, sosial budaya, pertahanan dan keamanan; 3) melaporkan data/informasi yang diperoleh terkait permasalahan yang terjadi di masyarakat secara berjenjang kepada Satuan Atas; 4) melakukan monitoring pelaksanaan program pembangunan yang dilaksanakan oleh pemerintah di Desa/Kelurahan; 5) Melakukan upaya-upaya penyelesaian konflik/persoalan hukum yang terjadi di masyarakat (restorative justice) dengan mengedepankan upaya musyawarah dan mufakat; 6) menjadi konsultan setiap persoalan yang dihadapi masyarakat (Pergub. No. 8 Tahun 2012, pasal 5).

Susunan organisasi forum mapalus kamtibmas terdiri dari: a) Pembina, adalah Forum Komunikasi Pimpinan Daerah Provinsi Sulawesi Utara; b) Pengawas, adalah Forum Komunikasi Pimpinan Daerah Kabupaten/Kota; c) Pengendali, adalah unsur Pimpinan di Kecamatan; d) Pelaksana, adalah Kepala Desa/Lurah/Hukum Tua/Sangadi/Opo Lao, Bhabinkamtibmas, Babinsa, LKMD, FKDM, Tokoh Agama, Tokoh Masyarakat dan Tokoh Adat (Pergub. No. 8 Tahun 2012, pasal 6).

Tugas Kepala Desa/Lurah adalah: 1) Mengkoordinir seluruh pokja Mapalus Kamtibmas dalam penanganan/pemecahan masalah Kamtibmas, bencana baik alam maupun non alam serta konflik komunal; 2) Mengkoordinir seluruh aparat desa/kelurahan guna membantu tugas pokja mapalus kamtibmas dalam penanggulangan/pemecahan masalah kamtibmas, bencana baik alam maupun non alam serta konflik komunal; 3) Memfasilitasi pihak-pihak terkait yang berhubungan dengan masalah kamtibmas, bencana baik alam maupun non alam serta konflik komunal; 4) Melaporkan setiap permasalahan kepada Pimpinan tertinggi (Camat); 5) Sebagai leading sektor dalam pemecahan masalah, bencana baik alam maupun non alam serta konflik komunal; 6) Mempersiapkan dukungan anggaran untuk pelaksanaan giat Mapalus Kamtibmas yang diajukan pada Camat (Pergub No. 8 Tahun 2012 Pasal 7).

Tugas Pokok Bhabinkamtibmas adalah: 1) Memfasilitasi setiap permasalahan yang terjadi guna mencari solusi untuk pemecahan masalah Kamtibmas, bencana baik alam maupun non alam serta konflik komunal; 2) Berkoordinasi dengan Pokja Mapalus Kamtibmas yang terdiri dari Kepala Desa, Babinsa dan Potmas guna menyelesaikan permasalahan Kamtibmas, bencana baik alam maupun non alam serta konflik komunal; 3) Membuat rencana dan laporan pelaksanaan kegiatan Mapalus Kamtibmas kepada Kapolsek selaku pembina pelaksana tingkat 
Kecamatan; 4) Melakukan deteksi dini setiap ada permasalahan Kamtibmas, bencana baik alam maupun non alam serta konflik komunal untuk segera diselesaikan pada Pokja Mapalus Kamtibmas; 5) Membina masyarakat yang menjadi tanggung jawab untuk dapat meningkatkan partisipasi masyarakat, kesadaran hukum dan ketaatan masyarakat terhadap hukum dan perundang-undangan yang berlaku; 6) Membangun kerjasama dalam rangka pemeliharaan dan penanggulangan kamtibmas dan konflik komual; 7) Menerima informasi dan keluhan serta permasalahan dari warga untuk diselesaikan secara bersama-sama; 8) Sebagai leading sektor terhadap permasalahan Kamtibmas dan konflik komunal (Pergub. No. 8/2012, pasal 8).

Tugas Pokok Babinsa adalah: 1) Koordinasi dalam penyelesaian masalah Kamtibmas di bidang Ideologi, Politik dan Keamanan dalam Negeri; 2) Membuat rencana dan laporan pelaksanaan Giat Mapalus. Kamtibmas kepada Danramil selaku Pembina Pelaksana tingkat Kecamatan; 3) Melakukan deteksi dini setiap permasalahan Kamtibmas di bidang Ideologi, Politik dan Keamanan untuk segera diselesaikan pada Pokja Mapalus Kamtibmas di tingkat Desa/Kelurahan; 4) Sebagai leading sektor terhadap permasalahan Kamtibmas di bidang ideologi, politik dan keamanan (Pergub. No. 8/2012 pasal 9).

Tugas Pokok Potmas adalah: 1) Melakukan koordinasi dengan pokja mapalus kamtibmas dalam penyelesaian permasalahan Kamtibmas, bencana baik alam maupun non alam serta konflik komunal; 2) Membantu pokja Mapalus Kamtibmas dalam memberikan pesan-pesan kamtibmas kepada masyarakat (Pergub. No. 8/2012 pasal 10).

Hubungan kerja dalam rangka kegiatan forum mapalus kamtibmas sesuai dengan Pergub. No. 8 Tahun 2012 pasal 11 sebagai berikut: 1) Menentukan kebijakan strategi Mapalus Kamtibmas agar dapat mengalokasikan sumber daya anggaran, materiil logistik dan personil; 2) Melakukan koordinasi antar instansi dalam rangka merencanakan Ren, Lak, Wasdal untuk pemberdayaan Mapalus Kamtibmas; 3) Mengarahkan, membimbing dan memberikan petunjuk serta arahan kepada pelaksana pengawas Mapalus Kamtibmas, agar dapat melaksanakan tugas pengawasan kepada Mapalus Kamtibmas dengan baik dan benar.

Selain itu forum mapalus kamtibmas melaksanakan tugas pokok, fungsi dan peranan masing-masing sesuai dengan peraturan perundang-undangan, melakukan pembinaan/pemberdayaan masyarakat desa, mencari dan mengumpulkan data/informasi tentang potensi bencana alam, non alam dan bencana sosial serta permasalahan di bidang Ideologi, politik, ekonomi, sosial budaya dan pertahanan keamanan. Forum mapalus kamtibmas melaporkan data/informasi yang diperoleh terkait permasalahan yang terjadi di masyarakat secara berjenjang, kepada satuan atas, melakukan monitoring pelaksanaan program pembangunan yang dilaksanakan oleh pemerintah di desa/kelurahan; melakukan upaya-upaya penyelesaian konflik/persoalan hukum yang terjadi di masyarakat dengan mengedepankan upaya persuasif, musyawarah dan mufakat; serta dapat menjadi konsultan setiap persoalan yang dihadapi masyarakat.

Pemerintah daerah perlu terus melakukan pengelolaan dan pembinaan terhadap warga masyarakat, terutama pada masyarakat yang multikultural. Hal ini dilakukan untuk mencegah gangguan keamanan dan ketertiban masyarakat. Pada sisi lain, struktur masyarakat yang multikultural dapat melahirkan kompleksitas permasalahan sosial, budaya, agama, ekonomi, serta keamanan. Untuk mengatasi kompleksitas permasalahan sekaligus mencegah gangguan keamanan dan ketertiban akibat kepentingan yang berbeda dalam kehidupan masyarakat yang multikultural, pemerintah daerah sudah tentu menggunakan pendekatan budaya (kearifan lokal), dimana kelompok-kelompok the primary group seperti; tokoh-tokoh adat, agama dan masyarakat dilibatkan secara aktif, serta nilai-nilai budaya 
lokal seperti; norma, tradisi, dan adat istiadat dijadikan sebagai instrumen dalam menyelesaikan berbagai permasalahan keamanana dan ketertiban yang dipicu oleh sentimen agama, budaya, ekonomi, asal daerah, serta konflik lainnya yang muncul dalam masyarakat.

Kebijakan mapalus kamtibmas sangat efektif untuk mengatasi permasalahan keamanan dan ketertiban karena menggunakan tradisi dan adat istiadat lokal, yaitu dengan melibatkan masyarakat. Perlunya keterlibatan masyarakat dalam hal ini tokoh masyarakat, tokoh agama yang berpengaruh sebagai mediator dan fasilitator dalam penyelesaian masalah kamtibmas tersebut, karena mereka ini memiliki wibawa dan dihormati pendapat maupun sarannya oleh warga masyarakat.

\section{F. Partisipasi Masyarakat dalam Menciptakan Keamanan dan Ketertiban Masyarakat}

Pentingnya partisipasi dikemukakan oleh Conyers (1995) sebagai berikut: pertama, partisipasi masyarakat merupakan suatu alat guna memperoleh informasi mengenai kondisi, kebutuhan, dan sikap masyarakat setempat, yang tanpa kehadirannya program pembangunan serta proyek-proyek akan gagal; kedua, bahwa masyarakat akan lebih mempercayai proyek atau program pembangunan jika merasa dilibatkan dalam proses persiapan dan perencanaannya, karena mereka akan lebih mengetahui seluk-beluk proyek tersebut dan akan mempunyai rasa memiliki terhadap proyek tersebut; ketiga, bahwa merupakan suatu hak demokrasi bila masyarakat dilibatkan dalam pembangunan masyarakat mereka sendiri.

Partisipasi masyarakat dalam pembangunan dapat berupa partisipasi individu ataupun kelompok. Artinya, partisipasi individu dalam kelompok disebutnya sebagai partisipasi individual, sedangkan keterlibatan kelompok atau masyarakat sebagai suatu kesatuan disebutnya sebagai partisipasi kolektif atau kelompok. Jadi, bila partisipasi itu dapat berupa partisipasi individual dan partisipasi kolektif, berarti bahwa partisipasi masyarakat dalam pembangunan desa melalui keamanan dan ketetiban dapat digerakkan secara langsung melalui individu-individu dalam masyarakat, atau secara langsung melalui kelompok-kelompok masyarakat Davis and Newstrom (1989).

Untuk memelihara partisipasi anggota masyarakat ataupun organisasi pada umumnya ada beberapa syarat yaitu adanya masalah yang memerlukan pemecahan, ada tujuan atau cita-cita, kondisi sosial dalam organisasi, mempunyai strategi, mempunyai obyek sebagai sasaran, memiliki wadah, dan saluran untuk mencapai tujuan. Davis (1989) mengemukakan tentang partisipasi bahwa "participation is defined as mental and emotional involvement of persons in group situations that encourage them to contribute to group goals and share responsibility". Pandangan tersebut mengandung empat ide dasar dalam pengertian partisipasi yaitu (a) harus ada tujuan kelompok terlebih dahulu, (b) harus ada dorongan untuk menyumbang atau melibatkan diri bagi tercapainya tujuan kelompok, (c) keterlibatan tersebut meliputi baik fisik, mental, maupun emosi, dan (d) harus ada rasa tanggung jawab bersama demi tercapainya tujuan kelompok.

Menggerakkan partisipasi masyarakat dalam pembangunan desa melalui individu-individu yang bersifat satuan-satuan kecil, yang memungkinkan terwujudnya peranan kelompok, yang disebut sence of belongingness atau rasa kesetiakawanan, akan sangat mempengaruhi anggota kelompok atau anggota masyarakat di dalam pelaksanaan pembangunan. Budiman yang ditegaskan kembali oleh Tjokroamidjojo (1985: 226) mengatakan bahwa untuk menggerakkan partisipasi rakyat dalam pembangunan diperlukan pemimpin- pemimpin formal yang memiliki legalitas dan pemimpin-pemimpin nonformal yang memiliki legitimitas.

Partisipasi masyarakat merupakan keterlibatan aktif masyarakat dalam proses penyusunan dan pengambilan keputusan yang berhubungan dengan 
penyelenggaraan pemerintahan. Dengan demikian kepentingan masyarakat dapat tersalurkan di dalam penyusunan kebijakan sehingga dapat mengakomodasi sebanyak mungkin aspirasi dan kepentingan masyarakat, serta mendapat dukungan masyarakat luas. Partisipasi masyarakat dapat dikelompokkan menjadi 2 (dua) macam bentuk partisipasi yaitu (1) Partisipasi Masyarakat muncul karena ketidakmampuan pemerintah atau (2) Partisipasi masyarakat murni swadaya masyarakat karena mereka butuh sesuatu.

Partisipasi masyarakat mutlak diperlukan agar penyelenggara pemerintahan dapat mengenal lebih dekat siapa masyarakat dan warganya, selanjutnya cara pikir dan kebiasaan hidupnya, masalah yang dihadapinya, cara atau jalan keluar yang disarankannya, apa yang dapat disumbangkan dalam memecahkan masalah yang dihadapi, dan sebagainya. Kehadiran dan keikutsertaan warga masyarakat dalam forum pertemuan publik, dan keaktifan mereka dalam menyumbangkan pikiran dan saran-saran menunjukkan bahwa urusan pemerintahan juga menjadi urusan mereka, dan bukan semata urusan birokrat sebagaimana terjadi selama ini.

Walaupun demikian harus diakui bahwa tidaklah mudah mengikutsertakan semua lapisan masyarakat dalam suatu forum sekaligus, sehingga jalan keluar yang diusulkan ialah memberi akses kepada wakil-wakil dari berbagai lapisan masyarakat untuk berpartisipasi dan menyuarakan kepentingan kelompok yang diwakilinya dan mengajukan usul serta pikiran dalam forum-forum pertemuan publik seperti Forum Mapalus Kamtibmas.

Wujud nyata dari prinsip ini ialah pembentukan forum-forum atau mekanisme pengambilan kebijakan publik yang memberi akses yang lebih luas kepada masyarakat untuk berpartisipasi, dan pemberian fasilitas berupa pelatihan-pelatihan kepada mereka yang mewakili masyarakat agar mampu merumuskan masalah yang dihadapinya seperti masalah keamanan dan ketertiban masyarakat, dan mampu menemukan cara pencegahan dan penyelesaian masalah yang tepat melalui forum-forum atau saluran publik yang ada (Bappenas, 2005).

Dengan demikian partisipasi publik dalam menjaga dan memelihara keamanan dan ketertiban masyarakat adalah keterlibatan secara aktif dari seseorang, atau sekelompok orang (masyarakat) untuk berkontribusi secara sadar dan sukarela dalam menjaga dan memelihara keamanan dan ketertiban masyarakat mulai dari perencanaan, pelaksanaan, pengawasan sampai pada tahap evaluasi, serta keikutsertaan dalam pencapaian tujuan untuk meningkatkan keamanan dan ketertiban masyarakat.

\section{KESIMPULAN DAN SARAN}

\section{KESIMPULAN}

Pada fokus ini dapat disimpulkan ada 4 (empat) indikator yakni (a) Kesadaran masyarakat dalam bentuk partisipasi menciptakan keamanan dan ketertiban; (b) Peran elit lokal dalam pembentukan partisipasi; (c) Dukungan Politik Pemerintah; (d) Hambatan Partisipasi masyarakat. Demikian yang dapat disimpulkan dari keempat indikator dari hasil temuan penelitian:

Kesadaran masyarakat dalam bentuk partisipasi menciptakan keamanan dan ketertiban masyarakat; hanya sebagian masyarakat saja yang secara sadar berpartisipasi dengan mengedepankan budaya Mapalus, namun lainnya perlu ada feedback bagi mereka, walaupun Mapalus sebagai nilai-nilai budaya Minahasa seperti gotong royong, tolong menolong, rasa kekeluargaan atau kebersamaan dan persaudaraan sudah ada sejak dahulu dan dipraktekkan di Minahasa demikian juga dalam menjaga keamanan dan ketertiban di dalam masyarakat. Tapi untuk nilai-nilai mapalus sudah mulai bergeser dari bentuk dan jenisnya. Misalnya saat ini hanya sebagian saja dalam kehidupan masyarakat Minahasa yang mempraktekannya. Misalnya jika ada yang kena musibah biasanya masih ada sebagian masyarakat yang secara bersama-sama bergotong royong saling membantu. Demikian juga jika terjadi masalah 
gangguan keamanan dan ketertiban ada juga sebagian dari masyarakat yang masih peduli atau berpartisipasi dalam mendamaikan dengan cara kekeluargaan. Tetapi jika tidak berhasil maka mereka segera melaporkan kepada pihak berwajib yaitu kepada aparat Kepolisian.

Peran elit lokal dalam pembentukan partisipasi; peran elit lokal dalam pembentukan partisipasi masih cenderung kurang dalam berpartisipasi. Yang ada dan terjadi hanya karena ada muatan kepentingan, yang condong berpartisipasi adalah tokoh agama. Para tokoh masyarakat yang ada dalam struktur forum Mapalus Kamtibmas secara formal mereka itu diisi dalam forum untuk dimasukkan tapi kenyataannya mereka tidak berfungsi.

Dukungan Politik Anggota DPRD hampir tidak pernah terlihat kecuali pada saat-saat kampanye. Biasanya mereka muncul hanya pada saat kampanye untuk merebut suara masyarakat tapi setelah itu hampir tidak pernah terlihat lagi. lembaga legislatif itu pula tidak pernah terlibat langsung dalam kegiatan mapalus kamtibmas. Peran lembaga legislatif sebagai bagian dari representatif masyarakat belum menjalankan tugas politiknya dalam menjalankan fungsi budgeting/penganggaran sehingga dukungan anggaran di tingkat kabupaten sama sekali tidak ada dan kurang mendukung.

Hambatan Partisipasi dapat disimpulkan bahwa hambatan yang utama partisipasi masyarakat ialah lemahnya sosialisasi dan koordinasi dari Pembuat kebijakan. Selanjutnya lemahnya koordinasi antara pemerintah Provinsi dengan Pemerintah Kabupaten secara vertikal. Selanjutnya pelibatan masyarakat hanya pada hal-hal yang sifatnya temporary atau sementara, dalam hal ini peran pemerintah sebagai pembuat kebijakan sangat lemah dan tidak optimal.

\section{SARAN}

Sebagai tindak lanjut terhadap temuan penelitian dan kesimpulan yang dikemukakan, maka dikemukakan saran-saran sebagai berikut: Perlu peningkatan partisipasi masyarakat yaitu peran elit lokal seperti tokoh masyarakat, tokoh agama, serta dukungan politik pemerintahan.

Perlu memperhatikan kearifan lokal Mapalus, menyiapkan sumber daya pendukung yang memadai, dan lebih responsifnya pemerintah daerah dalam mengimplementasikan kebijakannya dalam bentuk pengawasan dan transparansinya anggaran.

\section{REFERENSI}

[1] Bauer, Hunter. Civic Culture As A Policy Premise: Appraising Charlotte's Civic Culture. Journal of Urban Affairs, Volume 30, Number 4, page 389-417, 2008

[2] Friedman, Administrasi Negara Baru, Alih Bahasa AlGhozei Usaman. Jakarta: LP3ES, 1997

[3] Kalangi, N.S, "Kebudayaan Minahasa", dalam Koentjaraningrat, Manusia dan Kebudayaan di Indonesia. Jakarta: Djambatan, 2002

[4] Kasper, W. \& Streit M. E, Institution Economics, Social Order and Policy. Edward Elgar. Cheltenham: UK. And Northampton, MA, 1998

[5] Koentjaraningrat, Some Social-Anthropological Observations on Gotong Royong Practices in Two Village of Central Java, Cornell University Itacha, New York, 1961

[6] Manda, Darman, "Revitalisasi Peran Institusi Sosial, Transformasi Nilai Kearifan Budaya Lokal untuk Pencapaian Harmonisasi dan Solidaritas Sosial". Makassar: Pidato Pengukuhan Jabatan Guru Besar pada FIS Universitas Negeri Makassar, 2012

[7] Miles, Mathew, D. dan Huberman, A.M, Analisis Data Kualitatif. (terj.) Cecep Rokendi Rokidi. Jakarta: UI Press, 2007

[8] Nasution. S, Metode Penelitian Naturalistik Kualitatif. Bandung: Tarsito, 2003

[9] Parsons, Wayne, Public Policy; Terjemahan: Pengantar Teori dan Praktik Analisis Kebijakan. Jakarta: Kencana Prenada Media Group, 2011

[10] Peraturan Gubernur Sulawesi Utara No 08 tahun 2012 tentang Pembentukan Forum Mapalus Kamtibmas.

[11] Sarundajang, S. H, Babak Baru Sistem Pemerintahan Daerah. Jakarta: Kata Hasta, 2005

[12] Tangkau, Charles, Sound Governance sebagai Arah Baru Paradigma Pembangunan di Era Globalisasi (Analisa Kritis terhadap Good Governance). Bahan kuliah. Artikel, 2012 
[13] Tilaar, H.A.R. 2004, "Mapalus dalam Konteks Pengembangan Manajemen di Indonesia, Jakarta: Manajemen, Majalah Para Manajemen dan Eksekutif Indonesia, No. 32 Tahun VI. Jan- Feb 1986.

[14] Tjokrowinoto, Moelyano. Peranan Kebudayaan Politik dan Kebudayaan Administrasi di dalam Pembangunan Masyarakat Desa. Yogyakarta: Balai Pembinaan Adminsitrasi, UGM, 1977

[15] Undang-undang Nomor 32 Tahun 2004 tentang Pemerintahan Daerah, , Citra Umbara, Bandung.

[16] Wawointana, Thelma. 2003. Pelestarian Mapalus di Minahasa dalam Rangka Pengembangan Kebudayaan Nasional. Manado: Jurnal Ilmu-Ilmu Sosial, FIS Universitas Negeri Manado. Vol.1, Nomor 1, 
Jurnal Kajian Kebijakan dan Ilmu Adminstrasi Negara (Jurnal ADMINISTRO)

http://ejournal.unima.ac.id/index.php/administro 